\title{
FORMATION AND SUBSTANTIATION OF ANTI-CRISIS STRATEGY OF FINANCIAL SECURITY OF COUNTRIES WITH ECONOMIES IN TRANSITION
}

\author{
Oleksiy Getmanenko'
}

\begin{abstract}
The purpose of the article is to form and substantiate the anti-crisis strategy of financial security of countries with economies in transition. This need is due to the fact that the development of the world economy and international financial relations, strengthening integration processes in the world in times of the ongoing global financial instability, internal and external contradictions and imbalances in financial markets require the development of new ways to improve financial security. Methodology. In the course of the analysis, various concepts and directions of improving the financial security of the state were considered, using the methodology of system analysis in the study, which allowed to form the principles of anti-crisis strategy of financial security of countries with economies in transition. Results. The most important tasks of strategic anti-crisis management of financial security of the state on the way to its integration into the world economy are to ensure an effective integration of the financial component of the economy within the regional and global financial relations, to improve the efficiency of public administration and optimize the system of overcoming external and internal threats to financial security, conduct a policy of reasonable protectionism within the framework of generally accepted and effective procedures, as well as to maintain stability of the national currency and its moderate volatility, etc. Practical implications. The analysis of concepts and areas of improvement of financial security of the state allowed to formulate the principles of anti-crisis strategy of the financial security of countries with economies in transition and to develop practical recommendations for improving the process of financial security management in Ukraine. Value/originality. The use of systematic analysis allowed to formulate the principles of anti-crisis strategy of the financial security of countries with economies in transition in modern conditions.
\end{abstract}

Key words: anti-crisis strategy, financial security of a country, countries with economies in transition, international financial relations.

JEL Classification: F36, H12

\section{Introduction}

The development of the world economy and international financial relations, the strengthening of integration processes in the world in times of ongoing global financial instability, internal and external contradictions and imbalances in financial markets have led to the strengthening and spread of the following interrelated trends, risks and threats to global financial security.

Firstly, the openness of the world's economies and their financial markets, liberalization of international financial relations, integration of financial and foreign exchange markets, intensification of global capital movements have significantly strengthened the level of interconnectedness and interdependence of the world economy, global financial and economic system, economies and financial systems of the world, which have become whole.

Secondly, the interconnectedness and interdependence of the world economy and the global financial and economic system, which are dynamic and multi-coordinate, have made it a complex, vulnerable and prone to various risks and threats system for all member countries, due to the uneven development of the world;

Thirdly, the strengthening of the integration of the world economy, the turbulence of the global 
financial and economic system as well as the open economy is accompanied by various manifestations of instability of economic and financial markets, ineffective tools for regulating and controlling states and their lack of possibility to impact the turbulent environment.

Fourthly, the virtualization of economic relations, the development of the e-economy, the emergence of new agreements, products and transactions, turbulence and changes in the environment have led to a systematic transformation of the role of financial institutions and economic entities on the basis of common tasks and functions, new laws and paradigms, subject to the laws of synergy, and, consequently, the need to form fundamentally new approaches to their regulation at both global and national levels.

It should also be noted that both globally and at the level of an individual country, there is a constant emergence of various structural disparities, which are constantly increasing and are critical for both local and global financial security, as well as for the development of financial and economic systems. In view of this, in any country, the issue of developing ways to neutralize the risks and threats to financial security in the process of integration into the world economic relations at the national level comes to the fore. This is especially true in the countries with economies in transition. To reaffirm the importance of this step, it should be noted that following the United Nations Summit on Sustainable Development on 25 September 2015, 193 participating countries have committed themselves to a wide range of measures and structural changes to ensure macroeconomic stability and financial security of states, competitive development, ecological balance and social cohesion of national economies, etc. After all, even the market systems of developed countries were incapable of self-regulation: "the root causes of cataclysms are a utopian attempt by economic liberalism to create a self-regulatory market system" (Polanyi, 2001).

\section{Ways to neutralize the risks and threats to financial security of countries with economies in transition}

According to Professor R. Voitovych, the problem of the lack of formation of national identity prevents the state from fully resisting the globalization challenges of other states, to ensure a sufficient level of its own financial security.
According to the author, it is essential to develop a state globalization policy that would preserve the country's financial stability by taking into account the ratio of geostrategic forces in the global space and a clear definition of Ukraine's place and role in it. At the same time, globalization policy should be aimed primarily at the realization of national interests not by adapting to the needs of the global development system, but by being able to declare and defend their own nationally regulated position in the global world (Voitovych, 2013).

A. Kulinska in the monograph "Management of the components of financial security of the national economy of Ukraine: concept and methodology" offers methodological tools for managing the financial security of the national economy of Ukraine, which is to strengthen the interconnections between the components of financial security (Kulinska, 2016).

Somewhat similar proposals were put forward by O. Sidorov, who proposed a fairly general approach to economic security on the basis of the intellectual potential, which involved a certain sequence of stages of support, which included the formation of methodological and information bases, analytical assessment, threat detection and assessment, development provisioning mechanism. According to the scientist, this approach allowed to diagnose the state of the national economy based on the results of economic security assessment, to identify threats to economic security in the field of intellectual potential and to develop measures to eliminate them or overcome their consequences (Sidorov, 2018).

It is also necessary to highlight the proposals of some scholars on the possible ways to neutralize the risks and threats to financial security in the process of integration into the world economic relations, which are to manage certain components of financial security. Unfortunately, such a narrow specialization of the ways to neutralize risks and threats to financial security is not able to fulfill this task, because the country's financial security is a systemic category, and it is impossible to achieve its quality level only through the management of its individual components. Public financial policy and tools aimed at overcoming threats, risks and negative factors for the financial system and financial security of the country must combine a set of budget, tax, credit, monetary and other instruments. The need to use the instruments of all components of the country's financial security 
is due to the fact that the shortcomings and limited effects of some instruments must be offset by the advantages of others, it is necessary to create a comprehensive system of measures to strengthen and effectively develop both the country's financial system and financial security.

Let us now consider the proposals that have been developed by international structures. Thus, within the framework of the G20 in London on April 2, 2009 , a number of priority tasks were identified in reforming the system of the anti-crisis regulation of financial security at the national level:

- expanding the scope of financial regulation and its extension to most transactions in the financial market. Regulation must keep pace with innovation and focus more on operations rather than institutions;

- strengthening market discipline, eliminating the risk of an incorrect assignment of ratings. The identification of triggers that indicate the need for government intervention, as well as the development of a more transparent system of distribution of losses, are of particular importance for system-forming banks;

- minimization of pro-cyclicality in regulation, creation of reserves and airbags in a "peacetime". Regulators should continuously monitor market conditions so as not to encourage the financial institutions to take excessive risks;

- ensuring greater information openness, reliability of statistical data, their accurate reflection in the reports on financial stability, the creation of more transparent conditions for the assessment of complex financial instruments. Various market indicators (stock indices, option prices, CDS spreads) can contain important information about systemic risk. Obtaining information on the overthe-counter transactions and off-balance sheet transactions will expand regulators' understanding of the level of accumulated risk in the system;

- improving the efficiency of liquidity regulation in the financial system (G20 London, 2009).

According to experts of the international financial organizations, the priority for the country's financial security in the process of integration into world economic relations should be the integration of the national macroeconomic policy and tax system, as well as the financial regulation of capital flows. The IMF has already reconsidered its strong position on capital controls, but governments and international institutions need to do more to legitimize such measures. For example, governments can strengthen the stability of the national economy through "countercyclical regulation of capital", i.e. by limiting the inflow of capital if the economy is overheated, and by taxing the outflow of capital in the event of a recession. Governments must also combat tax evasion by creating a global financial register that records the place of residence and citizenship of shareholders and beneficial owners of financial assets.

Agreeing with the above positions and activities of scientists, organizations and states, it should be noted that they are either one-time, even when obtaining certain positive results, or aimed at solving operational problems, and so on. However, they are not a specific system and must be constantly reviewed and changed depending on the situation and the state of financial security of the country, which may lead to a waste of time in case of other, previously irrelevant risks or threats.

\section{The concept of strategic anti-crisis management of financial security of the state}

Given the above, we propose the concept of strategic anti-crisis management of financial security of the state, which should be implemented on the basis of strategic and preventive nature, should be aimed at continuously ensuring a level of financial security of the state at which it can protect its national interests, support socio-economic and financial stability of development, to be a participant in the world integration processes and international economic relations, which provides compliance of financial policy of the state (international, regional, national, local) long-term goals of sustainable development; constant complex interaction of all subjects of financial security management on all aspects of the financial security; constant control, monitoring and prevention of the existing and potential internal and external risks, threats, dangers and imbalances by building a vertically integrated risk management system at all levels of the economy; continuous development and improvement of tools for control, monitoring and avoidance of risks, threats, dangers and imbalances, overcoming their negative consequences and ensuring the financial security of the state.

At the same time, the model of strategic anticrisis management of financial security of the state should provide a list of various, consistent actions carried out in stages according to the algorithm:

1. Strategic diagnostics involves the implementation of system analysis: external and 
internal factors, challenges, dangers and threats; various geopolitical, economic and financial influences; trends and patterns of development of the world economy and the world financial system; state and trends of the financial system and security of the country, etc.

2. Strategic planning involves forecasting and planning the development of the financial system and financial security of the country within the economic security, as well as the establishment of the medium and long-term priorities of its operation. The result is the development of a strategy of financial security of the state as a political and economic course of the financial security management system of the state, the activities of state bodies, economic and financial structures, which aims to create conditions and resources for financial stabilization and economic growth.

3. Strategic implementation involves ensuring the required level of financial security of the country by coordinating and ensuring the effective interaction and functioning of all components and elements of systems; introduction of preventive, anticipatory and / or anti-crisis solutions, measures and tools.

4. Strategic monitoring involves the implementation of current and future monitoring and control, assessment of the state of financial security based on the relevant indicators; adjustment of the medium-andlong-term priorities of the strategy, adaptation and transformation of the operational decisions and actions, based on the results of strategic monitoring of the financial security system of the state.

Ensuring the quality implementation of this concept and achieving the greatest effect is possible only if the financial security management system of the state will be a set of the interconnected elements, which are characterized by the following system characteristics:

- mandatory presence of an ordered set of components, the functioning of which is determined by the established laws, norms and rules;

- the permanent nature of the relationships between the constituent elements that arise in the process of the system;

- flows of resources, information and energy both within the system itself and in the process of its interaction with the external environment;

- the presence of a clear hierarchical structure with the distribution of powers, duties, responsibilities and control centers in the implementation of the main functions of the system;

- ability to self-development and self-regulation of the system, forming its self-sufficiency and independence in the course of social exchange;

- the presence of a holistic system of properties and characteristics that are not inherent in its individual elements (Boiko, 2017).

The system of financial security management of the state should have such a structure that would be able to ensure clear functional and institutional interaction and coordination of all elements of the financial system. The main tasks of the financial security management system of the state include:

- ensuring coordination of various levels and components of the financial security, including the international security systems;

- identification of the internal and external threats to financial security;

- choice of ways and means to achieve goals and address financial security issues;

- formation of a set of measures capable of ensuring the achievement of goals and solving problems;

- coordination of actions of all participants of strategic anti-crisis management of the national financial security;

- ensuring monitoring, evaluation and control of the strategy implementation;

- financial, informational, personnel and other support of the strategy implementation process.

To confirm the correctness of the direction of improving financial security management, consider two opposite cases on the example of Poland, which partially implemented our principles and the principles of financial security management system, and an example of Argentina, where our principles and principles did not find a place.

Today, in Poland, there is a system of financial security management, which includes the Financial Stability Committee, the Ministry of Finance, the Financial Supervision Commission, the National Bank of Poland, the Bank Guarantee Fund, guarantee and compensation entities in the insurance and capital market, and the National Association credit unions. Each of the structures has specific tasks defined by the law both in case of crisis situations in the activities of individual institutions, and in case of crisis of the system as a whole (Masiukiewicz, 2014; Masiukiewicz, 2012).

The financial security management system of the Argentine Republic is no less presentable from an 
institutional point of view and includes a number of relevant regulations. The key institution of the financial security management system of the Republic of Argentina is the High Level Systemic Risk Monitoring Committee, which includes the Central Bank of the Republic of Argentina (BCRA - Banco Central de la Republica de Argentina), the Ministry of Economy and Public Finances (MECON), the National Securities Commission (CNV), the National Insurance Supervisor (SSN), and the Deposit Insurance Fund (FGD).

At the same time, the main problem of the systems and process of financial security management of these countries, as well as of Ukraine, is the lack of a financial security management system in the presence of conditions and appropriate regulatory and supervisory institutions.

\section{Risk management system as a subsystem of the financial security management system of the state}

Given the above, as well as returning to the functioning and efficiency of the financial security management system of the state and based on the requirements and features of systems theory and systems analysis, the criteria for monitoring and analyzing the functioning of the financial security management system should include:

- time order, which implies the need to take into account the state of functioning of the elements and the system as a whole and the dynamics of processes, taking into account the continuity of the management process;

- structural-spatial ordering as the spatial arrangement of system elements, and the establishment of different types of connections between them;

- information ordering as a subsystem of knowledge management, taking into account internal and external connections, fulfillment of functional responsibilities for functioning, security and selfdevelopment (Moiseenko, 2007).

This can be ensured through the risk management system as a separate subsystem of the financial security management system of the state.

The main task of this risk management system should be:

- identification and prevention of existing and potential systemic risks, dangers and threats of the external and internal origin, because they have caused and continue to cause the greatest negative and destructive impact on the financial security of a single state;

- assessment and determination of the necessary resources to neutralize risks, dangers and threats;

- planning and adjusting measures for the implementation of state policy in the field of financial security, etc.

To implement the above-mentioned risk management subsystem in Ukraine, it is possible to establish a permanent working group under the National Security and Defense Council of Ukraine or the Cabinet of Ministers of Ukraine. This Council should be instructed to lead not only the organizational and methodological work on the development of the financial security strategy and policy, but also the current regulation, monitoring of global risks and assessment of their impact on the financial security and the economy, as well as a timely identification of potential challenges, dangers and threats to financial security of Ukraine. As for the structure of the risk management subsystem, as well as the control, collection and analysis of information on systemic risks to financial security of Ukraine, we can offer the following distribution and responsibility of the state bodies and components of the financial security of the state, in order to identify and prevent the risks, implement the necessary measures and tools, given the systematic category of "financial security":

- Ministry of Economic Development, Trade and Agriculture of Ukraine: financial security of the state;

- Ministry of Finance of Ukraine: budget and debt security;

- National Bank of Ukraine: monetary banking, currency security and security of the non-banking financial sector;

- National Commission on Securities and Stock Markets of Ukraine: stock market security.

At the same time, a prerequisite for the effectiveness of this risk management system should be interconnected activities and comprehensive interaction of all its institutions, their quality regulation and administration within the entire financial security management system, as well as ensuring the implementation of a unified state policy on financial security, rather than a simple statistical performance of their own functional tasks, as it is happening today in the system of public administration of the financial system and security of the state. 


\section{Conclusions}

Thus, it can be noted that strategic anti-crisis management of the national financial security will address a number of important issues for the state, the main of which are the following:

- ensuring the financial stability of the state for a long period in all conditions, including by preventing and minimizing the effects of various crises (for example, crises of monetary, financial systems, etc.);

- neutralization of the negative impact of the world finances and economic expansion of the foreign and transnational companies on the national financial security;

- meeting all the necessary needs of society in financial resources and ensuring economic growth of the country;
- counteracting existing and potential dangers, risks and threats to ensure a stable functioning of the financial system, financial independence and identity of the state;

- ensuring the competitiveness of the state and the competitiveness of domestic producers in the world economy and the regional markets;

- ensuring the flexibility of legislation and compliance of national legislation with international standards;

- ensuring the protection of national and financial interests of the state and society in the context of growing globalization and integration of the country into international economic relations;

- ensuring effective control over the distribution and use of public funds;

- creating a favorable investment climate for foreign investment.

\section{References:}

Polanyi, K. (2001). The great transformation. The political and economic origins of our time. Boston: Beacon Press.

Voitovych, R. The impact of globalization on the development of the modern world. Available at: http://www.vidkryti-ochi.org.ua/2013/06/blog-post.html (accessed 20 June 2020). (in Ukrainian)

Kulinska, A. V. (2016). Upravlinnia skladovymy finansovoi bezpeky natsionalnoho hospodarstva Ukrainy: kontseptsiia ta metodolohiia [Management of components of financial security of the national economy of Ukraine: concept and methodology]. Odesa: FOP Bondarenko M. O. (in Ukrainian)

Sidorov, O. A. (2018). An approach to ensuring economic security based on intellectual potential. Black Sea Economic Studies, vol. 27(1), pp. 90-94. (in Ukrainian)

Boiko, V. V. (2017). Priorities and tools of rural development in the system of economic security of Ukraine: monograph. Lviv: NNVK "ATB" Publishing House. (in Ukrainian)

Masiukiewicz, P. (2014). Changes in the financial security system on the example of the Republic of Poland. IGEA News, vol. 4(96), pp. 162-170.

Masiukiewicz, P. (2012). Institutional system of financial security in Poland. Warsaw: SGH Publishing House.

Moiseenko, I. P. (2007). Management of intellectual potential: a monograph. Lviv: Avers. (in Ukrainian) Vlasiuk, O. S. (2014). Actual problems of financial security of Ukraine in the conditions of post-crisis transformation: monograph. Kyiv: NISR. (in Ukrainian) 